\title{
特集「民法改正の不動産実務への影響」にあたって Influence on the Real Estate Business by the Amendments of Civil Law
}

Yoshihisa MATSUDA

今回の，民法における債権関係の改正目的は，民法の「社会・経済の変化への対応を図ること」 と「国民一般に分かりやすい民法にすること」である。法制審議会の民法（債権関係）部会では， 2009年11月から審議が開始され，本年（2013年）2 月26日に「民法（債権関係）の改正に関する 中間試案」(以下，中間試案という) がとりまとめられた。そして，2014年 7 月を目標に要綱案の 策定，2015年の早い時期での改正要綱の取りまとめと法務大臣への答申が目指されている。

本特集は, 民法改正の意義, 民法改正によって変わる法実務, 中間試案が実現した場合に不動 産実務にどのような影響が生じることになるのか，などについて，総合的に取り上げ，今後の民 法と不動産との関わり，新たな法制度の展望などについて，多方面から論じたものである。

本特集の流れと各論説の概要を示すと, 次のとおりである。

1 ．法務省立法担当者による中間試案についての論説 法務省民事局参与である内田貴氏に，民 法改正の全般の意図, 意義, 経緯, 法改正の影響などの解説とともに, 不動産実務に影響を与 える「事情変更の法理」,「解除」,「保証」,「債権譲渡」, 中でも「将来債権譲渡」などについて 論じていただいた。

2. 不動産実務側の執筆者による論説 ここでは, 中間試案の改正内容のうち, 不動産実務への 影響がある論点について，多様な立場から論じていただいた。

（1）全般的な影響について ここでは, 不動産協会, 学者 (法学者, 経済学者), 弁護士がそ れぞれ異なる立場から論じている。まず，一般社団法人不動産協会が提出した中間試案に対 するパブリックコメントとその内容につき, 同協会事務局が解説している。このパブリック コメントは不動産業界を代表して不動産実務への影響を示しているものといえよう。法学者 の塩澤一洋氏は，民法改正の原点に焦点をあて，それに対する疑念，すなわち，「法目的の 明確化」と「体系的精緻性の確保」の必要性を提示し, 一般ルールなき個別ルールの列挙と いった中間試案の欠点を指摘し，不動産取引への影響を懸念している。

そして, 弁護士の柴田龍太郎氏は, 法律実務家の立場から, 契約全般, 売買契約, 賃貸借 契約に影響を与える事項とわかりやすくなっていない部分を取り上げ，論じている。特に契 約全般に影響があり, わかりやすくない部分として, 債務不履行における損害賠償請求の要 件とされてきた債務者の「責に帰すべき事由」が,「契約の趣旨に照らして責に帰すべき事由」 になることにつき，懸念を示している。

経済学者の安藤至大氏は, 経済取引に対する法介入の必要要件を経済理論により具体例を 用いて明快に説明した上で, その理論を適用した場合, 不動産取引で不利な立場にいると思 われる買主の保護, 不動産賃貸借契約における保証人, 賃借人の保護のために, 強い規制や 義務付けを行うことはかえって予期しない不利益が生じてしまうとして警鐘を鳴らしている。

(2) 特定の論点について ここでは不動産実務に影響を及ぼすことが懸念される中間試案の特 定の部分を取り上げ，より掘り下げた論説がなされている。 
(1)保証債務改正 金融実務家であった村田利喜彌氏が，金融実務家の立場から，個人保証の制 限, 契約締結時の説明義務, 情報提供義務, 主たる債務の履行状況に関する情報提供義務, その他の方策, 根保証等について論説している。中間試案では原則個人保証を禁止し, 例外 として，「いわゆる経営者」による個人保証を認めているが，「いわゆる経営者」を定義付け ることの困難性から，原則個人保証を自由にし，例外を禁止するスキームを提案している。 また，根保証の改正は不動産業者側にもかなりの影響があることを懸念している。

(2)将来債権譲渡の促進 改正により, 賃貸不動産を購入しても将来賃料のすべてが譲渡されて しまっており，賃貸人たる地位を取得したはずの買主はいっさい賃料を収受できないことも 起こり得る。この点につき, 弁護士の吉田修平氏は, 䀣念を表明する。すなわち, 将来賃料 債権の譲受人が賃貸人の地位を取得するとしても, 賃貸不動産を所有・占有していないので あるから，修繥義務等の賃貸人の義務が果たせなくなるとの指摘である。

(3)契約解除 債務不履行が契約をした目的達成を妨げるものでないときは解除できないとされ ている。この点につき, 弁護士の関葉子氏は, 解除権の行使が狭められる可能性があり, そ の場合, 個々の紛争に適した常識的かつ柔軟な判決がなされなくなると懸念を示す。その他 の解除問題についても異論を呈している。

(4)消費者契約法の趣旨が盛り込まれる 敷引特約や更新料など最高裁で有効と判断されながら, 改正民法の下では, 無効と判断される可能性が指摘されている。この点につき, 弁護士の澤 野順彦氏は，たとえば居住用建物賃貸借契約における事業者である賃貸人と消費者である 賃借人との間には情報量や交涉力に格差があることを主張し，中間試案に賛意を示すが，私， 松田はそれらの者の間にはもはや格差は存在しないものとして反意を表明しており，両者の 考えは明確に異なっている。

(5)賃貸不動産の譲渡における賃貸人の地位の留保特約＼cjkstart最高裁平成11年 3 月 25 日判例時報 1674 号61頁は, 賃貸人たる地位を売主に留保する旨の合意の効力を否定し, 賃貸人の地位は当然 に新所有者に移転するものとしているが, 中間試案では賃貸人の地位の留保特約を有効と している。この点につき, 松尾弘氏は, 賃貸人の地位を留保するにつき, 判例法理に照らし, 中間試案と比較しながら, さまざまな論点につき, 詳細に論じ, あるべき立法について検討 している。

6敷金 稲田和也氏は, 賃貸人の地位が旧所有者に留保された場合の賃借人の有する敷金返還 請求権の保護等につき検討している。

その他, 本特集で取り上げることができなかったもので, 不動産業務に影響するものとして, 買戻特約, 危険負担制度を排除し, それに代わるものとして給付危険の移転時期に関するルール の明文化, 消滅時効の原則的な時効期間を10年に統一するなどがある。これらの点についても今 後検討する必要があろう。

本特集で示した不動産実務にマイナスの影響を及ぼすと思われる中間試案の箇所が適切に修正 され，よりよい民法改正がなされることを切に望むしだいである。

これまでの法制審議会の民法 (債権関係) 部会での会議議事録, 中間試案等については法務省 HP内にある「審議会等」の「法制審議会一民法（債権関係）部会」」で閲覧・印刷できる。

出版編集委員 松田佳久（創価大学）

${ }^{1}$ http://www.moj.go.jp/shingil/shingikai_saiken.html 